\title{
AMD1 Gene
}

National Cancer Institute

\section{Source}

National Cancer Institute. AMD1 Gene. NCI Thesaurus. Code C102773.

This gene is involved in polyamine biosynthesis. 